\title{
3
}

\section{Punishment and Private Law: Some Comparative Observations}

\author{
SOLÈNE ROWAN
}

\section{Introduction}

'I want to endow the French law of civil liability with a new role, that is, to deter and sanction behaviours which, whilst not necessarily criminally punishable, are

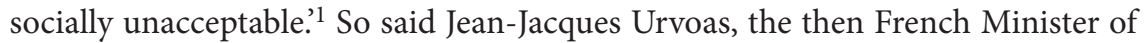
Justice, in 2016 when presenting new Article 1266-1 of the Civil Code in a draft bill for the reform of civil liability. ${ }^{2}$ This is perhaps the most controversial provision of the draft bill, providing for the introduction of civil penalties to deter and punish 'faults with a view to gain or making a saving. These penalties will be of general application in tort law and are intended to 'moralise behaviours.'

The publication of the draft bill and the proposed reform are significant events. Having reformed the section of the Code on contract law in 2016, the French Government is now turning its attention to tort law. ${ }^{4}$ Somewhat surprisingly, only five of the 2,281 articles of the original 1804 Code related to tort liability. These articles contain high-level propositions and general statements of principle. Just as surprisingly, the two most important articles, Articles 1382 and 1383 newly renumbered Articles 1240 and 1241 following the 2016 reform of contract law - have remained unaltered in the intervening two centuries, even as society and technology have changed beyond recognition. The courts have, however,

\footnotetext{
${ }^{1}$ G Marraud des Grottes, 'Interview with Jean-Jacques Urvoas' Revue Lamy Droit Civil (1 June 2016) 6211.

${ }^{2}$ J-J Urvoas, 'Projet de réforme de la responsabilité civile' (March 2017) at www.justice.gouv.fr/ publication/Projet_de_reforme_de_la_responsabilite_civile_13032017.pdf, accessed 22 March 2020.

${ }^{3}$ Interview with Jean-Jacques Urvoas (n 1). See also J-J Urvoas, 'Discours de présentation du projet de réforme' (Academy of Moral and Political Sciences, Paris, 13 March 2017) at www.presse. justice.gouv.fr/discours-10093/archives-des-discours-de-2017-12856/projet-de-reforme-de-laresponsabilite-civile-29780.html, accessed 22 March 2020.

${ }^{4}$ The draft bill also contains articles relating to aspects of liability for breach of contract, which have been left out of the 2016 contract reform.
} 
progressively interpreted and adapted these articles. Indeed, this has become so extensive that they are almost meaningless in isolation and without explanation.

High amongst the objectives of the draft bill is to modernise tort law by augmenting the Code with new provisions to replace the original articles. Rules that have been developed in the cases over the previous 200 years will be codified and clarified, and there are also several notable innovations. This chapter will focus on one such innovation, that is, the formal recognition that punishment should have a role in the law of tort. ${ }^{5}$ At present, nowhere is punishment stated to be an objective of French civil law. ${ }^{6}$ Instead, in both tort and contract law, remedies are, at least on their face, concerned only with compensating loss. The victim can expect to be returned insofar as possible to the position in which they would have been had the wrong not been committed. This is measured exclusively by reference to their loss. The seriousness of the wrong and the extent of any profit accruing to the wrongdoer are irrelevant.

The proposed introduction of a punitive sanction in the draft bill follows increasing calls in academic literature over the last 70 or so years ${ }^{7}$ for civil liability to go beyond mere compensation. These calls have intensified over the last three decades, with a high-water mark 15 years ago when a reform project gave serious consideration to the introduction of punitive damages. Whilst not ultimately obtaining legislative approval, this nonetheless laid the ground for the civil penalties that are proposed in the current draft bill. As one commentator imaginatively put it, "like the phoenix of the Greek mythology, the idea that punishment should have a role in private law dies only to be born again. ${ }^{8}$

The purposes of this chapter are twofold. First, to explore the historical controversies and reticence around the formal introduction of punishment in French civil law; second, to undertake a comparative analysis of the proposed punitive sanction in the draft bill by reference to English law. It seeks to show that remedies that are intended to deter and punish are already present in French civil law, coexisting disparately and informally with compensation as a central remedy. This has, however, proved insufficient to prevent a proliferation of 'profitable wrongs', so called because the wrongdoer aims to benefit from their wrongful conduct even after any compensatory liability is taken into account. Such wrongs are widely regarded as morally reprehensible yet can fall short of the criminal standard. It is to fill this perceived moral gap and give stronger protection to the rights of

${ }^{5} \mathrm{~J}$-S Borghetti, 'L'avant-projet de réforme de la responsabilité civile (1)’ D 2016.1442 [47]; E Dreyer, 'Lamende civile concurrente de l'amende pénale?' JCP No 25 Juin 2017, 1344; F Graziani, 'La généralisation de l'amende civile: entre progrès et confusions' D 2018.428.

${ }^{6}$ G Viney, 'Rapport de Synthèse' LPA 20 November 2002 No 232, 66.

${ }^{7} \mathrm{~B}$ Starck, Essai d'une théorie générale de la responsabilité civile, considérée en sa double-fonction de garantie et de peine privée, thesis, Paris University, 1947; S Carval, La responsabilité civile dans sa fonction de peine privée (Paris, LGDJ, 1995); A Jault, La notion de peine privée (Paris, LGDJ, 2005); $\mathrm{Z}$ Jacquemin, Payer, réparer, punir. Etude des fonctions de la responsabilité contractuelle en droit français, allemand et anglais, thesis, Paris University, 2015.

${ }^{8}$ Starck (n 7) 377. 
individuals that the French reformers have sought to introduce the new punitive mechanism of the draft bill.

In contrast with French law, the remedies that are available for profitable wrongs in English private law have been fortified with gain-based and punitive damages. The new civil penalty of the draft bill would bring about a rapprochement between French and English law. However, significant differences would remain. In particular, civil penalties have the potential to be materially more severe and punitive than the equivalent remedies in England.

\section{Disparate and Informal Manifestations of Punishment in French Civil Law}

Although deterrence and punishment are not formal objectives in the French private law sphere, they are familiar concepts that are present in many areas. ${ }^{9}$ The enforcement of penalty clauses, the disapplication of the remoteness rule resulting in larger awards of damages where wrongful conduct is deliberate, and the monetary sanction for non-compliance with court orders are just a few examples.

\section{A. Punishment through Penalty Clauses}

The validity of both liquidated damages clauses, which fix the amount of compensation payable for a breach of contract, and penalty clauses, which aim to deter and punish breach, is recognised in French law. ${ }^{10}$ Penal awards were justified by the draftsmen of the 1804 Civil Code as an 'excellent expression of morality in forcing people to perform the obligations that they have undertaken. ${ }^{11}$ French courts have the power to reduce the amount of an agreed penalty that is 'manifestly excessive $^{12}$ so as to curtail abuse, but without extinguishing its deterrent and punitive functions. The power is exercised only exceptionally ${ }^{13}$ where the disproportion is extreme. ${ }^{14}$ The agreed sum will not be capped at the amount of the actual loss ${ }^{15}$ and commonly only the excess is removed. ${ }^{16}$ As such, any reduction will not, as a general rule, completely deprive the award of coercive and punitive effect.

\footnotetext{
${ }^{9}$ Carval (n 7); Jault (n 7); Jacquemin (n 7) [258]-[348].

${ }^{10}$ French Civil Code 2016, Art 1231-5; Draft Parliamentary Bill 2017, Art 1284.

${ }^{11} \mathrm{P}-\mathrm{A}$ Fenet, Recueil complet des travaux préparatoires du code civil, vol 13 (Paris, Videcoq, 1836) 324.

${ }^{12}$ French Civil Code 2016, Art 1231-5.

${ }^{13}$ F Chabas, 'La réforme de la clause pénale' (L No 75-597 du 9 juillet 1975)' D 1976 Chron 229, 234; Y-M Laithier, 'Clause pénale et dommages et intérêts incitatifs' in C Jamin (ed), Droit et Économie des contrats (Paris, LGDJ, 2008) 141.

${ }^{14} \mathrm{G}$ Viney and P Jourdain, Traité de droit civil, Les effets de la responsabilité, 3rd edn (Paris, LGDJ, 2010) [256].

${ }^{15}$ Com 23 January 1979, Bull civ IV no 30; Com 29 January 1991, Bull civ IV no 43.

${ }^{16}$ Paris 20 June 1995, D 1995.IR.187.
} 


\section{B. Punishment of Deliberate Wrongs: Disapplication of the Remoteness Rule and Inflated Damages Awards}

The operation of the remoteness principle in contract law also reveals the latent presence of punishment in French law. Pursuant to Article 1231-3 of the Civil Code, ${ }^{17}$ the defaulting party must compensate only those consequences of nonperformance that were reasonably foreseeable when the contract was concluded. If, however, the breach is grossly negligent (faute lourde), deliberate or dishonest $(d o l)$, this rule is disapplied and liability extends to all consequences flowing from the breach. Reliance on exclusion and limitation clauses is also not permitted, and it is forbidden to seek indemnification under an insurance policy.

The approach of French courts has been to apply this exception to the remoteness principle expansively. There is no requirement to prove an intention to cause harm. It suffices for the defaulting party wilfully to refuse to perform their obligations. ${ }^{18}$ It is therefore far from unusual for compensation to be ordered for all consequences flowing from a breach. One example is where an airline had overbooked flights and was unable to carry every passenger who had bought tickets. By reference to old Article 1150 of the Civil Code, which was the predecessor of new Article 1231-3, the airline was ordered to compensate passengers for all losses arising out of the breach and was unable to rely on a limitation clause. ${ }^{19}$

Additionally, in both contract and tort cases, academic writing has shown a tendency on the part of lower courts, consciously or otherwise, to vary the quantum of damages in accordance with the culpability of the defaulting party. ${ }^{20}$ This is most evident with awards for non-pecuniary losses, which in France are compensated on a wide basis and involve putting figures to intangibles. This is possible because the assessment of damages is at the discretion of first instance and lower appeal courts. Provided that their decisions do not disclose any punitive intention, the Cour de cassation will not interfere. An extreme example is a hardly disguised punitive award of $€ 100,000$ that was ordered against the energy company Total to 'compensate' the non-pecuniary damage of the Bird Protection League, suffered as a result of the harm caused to sea birds by oil that spilled from the vessel, Erika, in 1999.21

\footnotetext{
${ }^{17}$ Its predecessor before the 2016 reforms was Art 1150 of the 1804 Civil Code.

${ }^{18}$ Civ 4 February 1969, D 1969.601 noted by J Mazeaud; Com 19 January 1993, JCP 1993.I.711.

${ }^{19}$ Paris 15 September 1992, D 199398 noted by P Delebecque.

${ }^{20}$ Viney (n 6) 66; D Fasquelle, 'Lexistence de fautes lucratives en droit français' LPA 20 November 2002 No 232 27, [18]-[24]; J-S Borghetti, 'Punitive Damages in France' in H Koziol and V Wilcox (eds), Punitive Damages: Common Law and Civil Law Perspectives (New York, Springer, 2009) 62-66; I Vingiano-Viricel, 'La faute lucrative: une notion en construction en droit français' RTD Com 2017.19, [7]-[12].

${ }^{21}$ Cited by TGI Paris 16 January 2008, no 9934895010, D 2008.35q and 2681, noted by L Neyret, JCP ed G 2008.II.10053 noted by B Parance, 251; Borghetti (n 20).
} 


\section{Punishing Non-Compliance with Court Orders: The Astreinte}

A further example of punishment is the astreinte. ${ }^{22}$ This enforcement device coerces compliance with court orders ${ }^{23}$ by applying financial pressure on the defaulting party. It takes the form of a monetary penalty payable to the victim for each additional period of default, usually in days, weeks or months, after the order is made. So as to be effective, the penalty is generally greater in amount than any advantage that the defaulting party would stand to gain from non-compliance. ${ }^{24}$ Few fortunes are able to resist indefinitely. ${ }^{25}$

The astreinte is unequivocally punitive in nature. ${ }^{26}$ It is granted in terrorem in the belief that 'it is necessary to frighten, almost terrorise, to incite performance. ${ }^{27}$ This is reinforced by the astreinte's being uninsurable, ${ }^{28}$ and by the willingness of French courts to take any abusive persistence in non-compliance and bad faith into account when assessing the final sum to be paid. ${ }^{29}$

\section{A Step Further: The Formal and General Introduction of Punishment in Civil Law}

Since punishment in the civil sphere is already known in France, a number of commentators have argued that its existence should be formalised and developed in those contexts where the existing array of civil remedies is too weak. The paradigm is profitable wrongs, against which compensatory damages and the criminal law do not adequately protect. These arguments have resulted in several proposals to introduce punitive damages, gain-based damages and, more recently, civil penalties into French law.

\section{A. The Objection to Profitable Wrongs}

A common denominator of profitable wrongs is that the beneficial consequences for the wrongdoer would not be undone by the simple reparation of any harm

\footnotetext{
${ }^{22}$ Carval (n 7) [36]-[41]; Jault (n 7); S Rowan, Remedies for Breach of Contract: A Comparative Analysis of the Performance Interest (Oxford, Oxford University Press, 2012) 44-45.

${ }^{23}$ Especially specific performance and injunctions or orders to protect the privacy rights of claimants.

${ }^{24} \mathrm{C}$ Hugon, 'Regard sur le droit des voies dexécution' RDC 2005.183, Civ 20 Oct 1959 D1959.537 noted by G Holleaux.

${ }^{25}$ W Jeandidier, 'L'exécution forcée des obligations contractuelles de faire' RTD civ 1976.700.

${ }^{26}$ Y Chartier, La réparation du préjudice (Dalloz Paris, 1983) [762]-[767].

${ }^{27}$ Hugon (n 24) 193.

${ }^{28}$ Civ 1, 20 March 1989, Bull civ I no 122; Viney and Jourdain (n 14) [6-5].

${ }^{29}$ TGI Paris 31 January 1984, D 1984.283 noted by R Lindon; Civ 1, 20 October 1959, Bull civ I no 419 .
} 
which it has caused. ${ }^{30}$ They occur where the wrongdoer intends that, even taking into account any liability to compensate the losses that flow from their default, they will make a profit or save money. ${ }^{31}$ In France these wrongs have been characterised as 'morally condemnable,'2 'morally shocking', 33 'socially and economically harmful' ${ }^{34}$ and 'unacceptable.' 35 Two elements are thought to be particularly objectionable. First, that one party can infringe the private rights of others, simply by paying compensation; second, that they do so intentionally with the calculation of making a gain. ${ }^{36}$ The outrage lies in the deliberateness of the wrongdoing and the disregard of the law and the rights of others. Both are violated with impunity and to exploit a deficiency in the available remedies.

Profitable wrongs are thought to have become more problematic and frequent in the last 50 years. This has been attributed in French commentary to the development of industrial activities, mass consumption and new technologies. General factors are blamed, such as increased market competition and pressure on businesses to 'give precedence to profit over legal or moral considerations. ${ }^{37}$ Although no empirical study has been undertaken of the frequency and areas in which profitable wrongs occur, commentators have cited a wide variety of areas in which they are apparently recurrent. These encompass the law of privacy, defamation, unfair competition, environmental law and consumer law. ${ }^{38}$ Commonly cited is the publication of photographs of celebrities in magazines and newspapers, intentionally infringing their rights to privacy in order to boost sales. The profit generated may well exceed the compensable loss caused to the celebrity. Another illustration is wrongfully causing pollution in the knowledge that any eventual sanction is likely to be less onerous than the cost of disposing of the pollutant lawfully. ${ }^{39}$

\footnotetext{
${ }^{30}$ G Viney, 'Exposé des motifs: Sous-titre III. De la responsabilité civile (Article 1340 a 1386)' in Avant-projet de réforme du droit des obligations et de la prescription: Rapport remis au garde des Sceaux (Paris, La Documentation française, 2006) 159, 168.

${ }^{31}$ Fasquelle (n 20) 30; G Viney, 'Projet de réforme du droit des obligations: les Éléments clés en matière de droit de la responsabilité Revue Lamy Droit Civil 2005 No 22.

${ }^{32}$ Graziani (n 5); J Meadel, 'Faut-il introduire la faute lucrative en droit français?' LPA 17 April 2006 No 77, 6; Y-M Laithier, 'Le prononcé de dommages- intérêts punitifs en cas de faute lucrative' in $\mathrm{N}$ Ferrier and A Pélissier (eds), Lentreprise face aux Évolutions de la responsabilité civile (Paris, Economica, 2012) $117,117-18$

${ }^{33}$ Fasquelle (n 20) 28; P Jourdain, 'Rapport introductif' in 'Faut-il moraliser le droit français de la réparation du dommage? (Â propos des dommages et intérêts punitifs et de l’obligation de minimiser son propre dommage)' LPA 20 November 2002 No 232, 3-4; M Chagny, 'La notion de dommages et intérêts punitifs et ses repercussions sur le droit de la concurrence - Lectures plurielles de l'article 1371 de l'avant-projet de réforme du droit des obligations' JCP G 2006 I 149.

${ }^{34}$ Dreyer (n 5); B Javaux, 'L'amende civile, entre sanction pénale et punitive damages?' JCP Gen No 6 11 February 2019, 152.

${ }^{35}$ Graziani (n 5).

${ }^{36}$ E Dreyer, 'La sanction de la faute lucrative par l'amende civile' D 2017.1136.

${ }^{37}$ Fasquelle (n 20) 4.

${ }^{38}$ Fasquelle (n 20) 30; Jourdain (n 33) 4; Carval (n 7); Laithier (n 32) 118; M Cappelletti, 'Comparative Reflections on Punishment in Tort Law' in J-S Borghetti and S Whittaker (eds), French Civil Liability in Comparative Perspective (Oxford, Hart Publishing, 2019) 329.

${ }^{39}$ Jourdain (n 33) 4.
} 
A well-known example is the Yves Saint Laurent case decided by the Court of Appeal of Paris in 1993. ${ }^{40}$ Yves Saint Laurent, a luxury fashion house, launched a perfume bearing the name 'Champagne', and was promptly sued by producers of the famous sparkling wine of the same name and the Office for the Protection of Protected Appellations. It was alleged to have used the word 'Champagne' in breach of legislation that protects product names, with a view to benefiting from the global renown of the wine. The Court of Appeal found against Yves Saint Laurent and ordered that it cease using the name, withdraw the perfume from sale and pay 150,000 French Francs in compensation. However, it was a decision that had no substantive negative economic effect for Yves Saint Laurent, which boasted of having lost in the eyes of the law but won economically. Its profit was far greater than the compensation awarded and the cost of removing the perfume from the shelves. The highly publicised trial had boosted sales, which yielded 200 million French Francs in the first three months post-launch and left stocks empty anyway.

\section{B. Punitive Damages, Gain-Based Damages or Civil Penalties as the Most Suitable Mechanism?}

Commentators have therefore argued ${ }^{41}$ that financial incentives to break the law for profit should be neutered. This is to fill a perceived moral gap and better protect private law rights that neither civil law remedies nor the criminal law adequately protect. These arguments have been met with general support from reformers but without any clear agreement on the most appropriate solution.

\section{i. Punitive Damages}

The introduction of punitive damages ${ }^{42}$ was considered relatively recently in the 'Proposals for Reform of the Law of Obligations and the Law of Prescription', commonly referred to as the 'Catala proposals. ${ }^{43}$ These proposals were made

\footnotetext{
${ }^{40}$ Paris 15 December 1993, No 19930474.

${ }^{41}$ See n 7; Graziani (n 5); J Prorok, 'Lamende civile dans la réforme de la responsabilité civile. Regard critique sur la consécration d’une fonction punitive Générale’ RTD Civ. 2018. 327.

${ }^{42}$ S Rowan, 'Comparative Observations on the Introduction of Punitive Damages in French Law' in J Cartwright, S Vogenauer and S Whittaker (eds), Reforming the French Law of Obligations, Comparative Reflections on the Avant-projet de réforme du droit des obligations et de la prescription ('the Avant-projet Catala') (Oxford, Hart Publishing, 2009) 325. See also the Proposal of the Beteille Law of 9 July 2010 (proposition de loi No 657), which provided for punitive damages to be introduced for deliberate faults with a view to gain, subject to an upper limit of twice the amount of the compensatory damages awarded.

${ }^{43}$ Avant-Projet de Réforme du Droit des Obligations (Art 1101 à 1386 du Code civil) et du Droit de la Prescription (Art 2234 à 2281 du Code Civil) under the direction of P Catala, 22 September 2005 (Documentation Française, 2006) translated into English by J Cartwright and S Whittaker: at www. justice.gouv.fr/art_pix/rapportcatatla0905-anglais.pdf, accessed 22 March 2020. See also Cartwright, Vogenauer and Whittaker (eds) (n 42).
} 
in 2005 against the background of the bicentenary of the Civil Code. Aimed at revising the articles of the Code relating to the law of contract, civil liability, unjust enrichment and prescription, they were considered by many to be the most ambitious attempt to reform the core areas of French private law since the creation of the Civil Code in $1804 .^{44}$

Draft Article 1371 of the Catala proposals provided that

A person who commits a manifestly deliberate fault, and notably a fault with a view to gain, can be condemned in addition to compensatory damages to pay punitive damages, part of which the court may in its discretion allocate to the Public Treasury. A court's decision to order payment of damages of this kind must be supported with specific reasons and their amount distinguished from any other damages awarded to the victim. Punitive damages may not be the object of insurance.

The scope of the draft article was wide, encompassing contract as well as tort, going beyond profitable wrongs and applying regardless of the motives of the defaulting party. All 'manifestly deliberate faults', of which 'fault with a view to gain' was just one example, would have sounded in punitive damages. The remedy would also have been available where the wrongdoer acted not for profit but maliciously. ${ }^{45}$

Article 1371 generated considerable interest and extensive comment. Reactions were mixed. Many endorsed the proposed introduction of punitive damages, ${ }^{46}$ but others were more circumspect. A recurrent concern was that there would be undeserved windfalls and the seminal principle of civil liability, that the injured party must be compensated not only fully but also commensurately with their loss (principe de la réparation intégrale), would be infringed. ${ }^{47}$ There were also fears of a litigation boom, as well as of arbitrariness and excess in the quantum of damages awards similar to the practice in the United States. ${ }^{48}$ Other criticisms included the lack of guidance as to the circumstances in which part of the punitive award should be directed to the state and in what proportion. ${ }^{49}$

\footnotetext{
${ }^{44} \mathrm{~S}$ Vogenauer, 'The Avant-projet de réforme: An Overview' in Cartwright, Vogenauer and Whittaker (eds) (n 42) 3.

${ }^{45}$ In this way, avoiding a criticism made by English commentators of Lord Devlin's second category in Rookes v Barnard [1964] AC 1129 (HL) that it does not allow punitive damages to be awarded where the wrongdoer acts not for profit but maliciously: Broome v Cassell [1972] AC 1027 (HL) 1088 per Lord Reid, who thought that the distinction between greed and malice could be justified only by reference to authority. See also Lord Nicholls in Kuddus v Chief Constable of Leicestershire Constabulary [2001] UKHL 29, [2002] 2 AC 122 [67].

${ }^{46}$ Borghetti (n 20).

${ }^{47} \mathrm{M}$ Behar-Touchais, 'Lamende civile est-elle un substitute satisfaisant a l'absence de dommages et interest punitifs?' LPA 2002, 36; Borghetti (n 20) [47]; Prorok (n 41).

${ }^{48} \mathrm{~S}$ Carval 'Lamende civile' in 'Avant-projet de loi portant reforme de la responsabilite civile, Observations et propositions de modifications' JCP suppl 25 July 2016 42, [7]; Javaux (n 34); Borghetti (n 20) citing L Engel, 'Vers une nouvelle approche de la responsabilité. Le droit français face à la dérive américaine' Esprit 1993.

49 'Rapport du groupe de travail de la Cour de cassation sur l'avant-projet de réforme du droit des obligations et de la prescription' 15 June 2007. See also S Rowan, 'Reflections on the Introduction of Punitive Damages for Breach of Contract' (2010) 30 OJLS 495.
} 


\section{ii. Gain-Based Damages}

Whilst the Catala proposals were never enacted, Article 1371 proved to be the trigger for wider discussion and analysis of how best to tackle profitable wrongs. The criticisms made of punitive damages led to gain-based damages being proposed as an alternative by a competing reform project led by a group of academic lawyers. In their Article 120, they proposed that in case of deliberate breach, the injured promisee may be awarded [instead of compensatory damages] all or some of the profit resulting from the breach, ${ }^{50}$

This was met with broad approbation ${ }^{51}$ as a less drastic and more proportionate solution, but there were also concerns that it would be too weak. As it is limited to gains accruing from the wrongful conduct, a party tempted to commit a profitable wrong might form the view that they have little to lose. The punitive and deterrent effect at the core of punitive damages would be removed. ${ }^{52}$

\section{iii. The Latest Proposal: Civil Penalties}

The mechanism proposed by the most recent (and likely to be enacted) reform project is the civil penalty (amende civile). This is seen by the draftsmen as a middle ground between punitive damages and gain-based damages. ${ }^{53}$ Draft Article 1266-1 provides:

In extra-contractual matters, where the author of the harm has deliberately committed a fault with a view to gain or making a saving, a court may, at the request of the victim or the ministère public (the state) and by specially reasoned decision, order payment of a civil penalty.

This penalty is proportionate to the seriousness of the fault, the financial means of the wrongdoer, and the profit gained from the wrongful conduct.

The penalty cannot be more than tenfold the amount of the profit gained.

If the wrongdoer is a corporation, the penalty can be up to $5 \%$ of the amount of the highest turnover before tax made in France in the tax years since the year preceding that when the fault was committed.

This penalty is directed to the financing of a compensation fund related to the nature of the harm suffered or, failing this, to the public treasury.

It is not insurable.

Civil penalties already exist in various areas of French law. ${ }^{54}$ They are intended to deter and punish acts that are reprehensible but not sufficiently serious to justify

\footnotetext{
${ }^{50}$ Terré Reform Project, Art 120.

${ }^{51} \mathrm{R}$ Mesa, 'Lopportune consécration d'un principe de restitution intégrale des profits illicites comme sanction des fautes lucrative' D 2012.2754; Carval (n 7). See also Z Jacquemin, 'Pour une reconnaissance de la spécificité contractuelle dans les effets de la responsabilité’ RDC 2016.808; Laithier (n 13); (n 32).

${ }^{52}$ Prorok (n 41)

${ }^{53}$ Urvoas (n 3).

${ }^{54}$ Behar-Touchais (n 47); Jault (n 7) [402]; Borghetti (n 20) [18]-[21].
} 
criminal liability. This includes the breach by state officials of some of their public duties; ${ }^{55}$ bringing court proceedings abusively $;{ }^{56}$ demolishing a building without the requisite permission, ${ }^{57}$ using a building for commercial purposes where only residential occupation is permitted, ${ }^{58}$ and restrictive competitive practices. ${ }^{59}$ Article 1266-1 would make these penalties generally applicable in the law of tort for profitable wrongs.

Civil penalties are proposed as a compromise between punitive and gain-based damages. ${ }^{60}$ On the one hand, they are clearly deterrent and punitive in nature and a more potent remedy than gain-based damages. This is most evident in the quantum of the award being dependent on the gravity of the fault and potentially much higher than the profit made from the wrong, and indeed very high in absolute terms. ${ }^{61}$ It is also obvious from the preclusion in Article 1266-1 of insurance against the risk of punitive awards so to uphold their punitive and deterrent effects.

On the other hand, civil penalties are better suited to the legal tradition of French law, and as such avoid some of the criticisms made of punitive damages. ${ }^{62}$ Since they would be paid to a designated fund set up to counteract at a general level the negative consequences of the wrong, they would not benefit the victims directly. The cardinal principle that the victim should not be awarded more than compensation would therefore be preserved. ${ }^{63}$ This is seen to be consistent with the main purpose of civil liability, which is the reparation of wrongs. ${ }^{64}$

\section{Remedies for Profitable Wrongs in English and French Civil Law}

In contrast with France, English law has long grappled with the problem of profitable wrongs. It has also shown similar hesitation as to whether punitive or gain-based damages are the most suitable response.

\section{A. Tackling Profitable Wrongs in English Tort Law}

Whilst the principal purpose of damages in English civil law is to compensate loss, in certain narrowly drawn circumstances, awards that are punitive and deterrent in

${ }^{55}$ French Civil Code, Art 50.

${ }^{56} \mathrm{New}$ Code of Civil Procedure, Art 32-1.

${ }^{57}$ Urban Code, Arts L430-2 and L430-9.

${ }^{58}$ Construction and Habitation Code, Arts L631-7 and L651-2. See also Arts 395, 412, 413 of the Civil Code, which sanction the avoidance of tutorship duties; or Art 207 of the New Code of Civil Procedure, which sanctions the avoidance of duties owed by witnesses at trials.

${ }^{59}$ Code of Commerce, Arts L442-1-L442-8.

${ }^{60}$ Urvoas (n 3).

${ }^{61}$ Dreyer (n 5); Prorok (n 41).

${ }^{62}$ Carvl (n 48); Urvoas (n 2).

${ }^{63}$ Borghetti (n 20) [50]; Dreyer (n 5) [13]; Prorok (n 41); Graziani (n 5); Cappelletti (n 38).

${ }^{64}$ Borghetti (n 20) [47]; Urvoas (n 3); Prorok (n 41); Graziani (n 5). 
nature may be ordered in tort law. ${ }^{65}$ The starting point is the classic speech of Lord Devlin in Rookes $v$ Barnard, ${ }^{66}$ in which awards of punitive damages were held to be restricted to three situations: first, where there is 'oppressive or unconstitutional action by the servants of the government', which covers the abuse of executive power; second, where the 'defendant's conduct has been calculated by him to make a profit for himself which may well exceed the compensation payable'; ${ }^{67}$ and, third, where expressly authorised by statute. ${ }^{68}$

Lord Devlin's second category is in substance similar to the 'fault with a view to gain or making a saving' in draft Article 1266-1. It targets the wrongdoer who 'with a cynical disregard for a plaintiff's rights has calculated that the money to be made out of his wrongdoing will probably exceed the damages at risk. ${ }^{69}$ The same kind of conduct is therefore considered as particularly reprehensible and deserving of punishment in both France and England. No tolerance is shown towards a person who cynically disregards the victim's rights for profit. Such behaviour brings the law into disrepute and should be deterred.

In practice, and contrary to conventional wisdom, ${ }^{70}$ the most common type of case in which punitive damages are awarded under Lord Devlin's second category involves claims for wrongful eviction, ${ }^{71}$ while actions in defamation and privacy invasion do not constitute an important source of punitive damages awards under the second category (or otherwise). ${ }^{72}$ This is notable from a comparative perspective. No mention is made in the French academic literature of profitable wrongs committed by landlords wrongfully harassing and/or evicting their tenants. Indeed, the most commonly cited example is the breach of 'personality' and privacy rights for gain.

Explanations offered by commentators in England for the significance of punitive damages in landlord and tenant cases include that an important function of English tort law is to protect property interests; and that police and local authorities may be reluctant to prosecute landlords who wrongfully evict tenants, leaving a lacuna in the criminal law that effectively forces claimants to seek private law redress. ${ }^{73}$ It may be that in France the state is more willing to protect tenants than in England, although it is hard to say whether this is indeed the case. Article 226-4 of the Penal Code enables a landlord who enters the rented property without the permission of the tenant to be fined up to $€ 15,000$ and imprisoned for up to one year. Civil liability arises under Article 1719, para 3 of the Civil Code, which

\footnotetext{
${ }^{65}$ For arguments that they should be available for equitable wrongs, see A Burrows, Remedies for Torts, Breach of Contract, and Equitable Wrongs, 4th edn (Oxford, Oxford University Press, 2019) $525 \mathrm{ff}$.

${ }^{73}$ ibid, although there are criminal sanctions against landlords for wrongful eviction under the Protection from Eviction Act 1977 (UK) (as amended by the Housing Act 1988 (UK)).
} 
protects the right of tenants to peaceful enjoyment of the rented property, and Article 9 of the Code, which protects a right to private life. ${ }^{74}$

Although punitive damages have long been available in England, ${ }^{75}$ they have nonetheless been controversial, generating similar discussions to those that have occurred in France. They have been described as anomalous, ${ }^{76}$ as confusing the role of the civil and criminal law, and (famously) as 'out of place, irregular ..., exceptional, unjust, unscientific, not to say absurd and ridiculous when classed among civil remedies, ... a monstrous heresy, ... an unhealthy excrescence, deforming the symmetry of the body of the law.77 It has been argued that gain-based damages would therefore be more acceptable in a civil law context.

At present, the gain-based remedy of an account of profits is only available for torts that involve infringements of intellectual property rights, for instance the infringement of patents, copyrights, trademarks and passing off. ${ }^{78}$ Profitable wrongs are mainly tackled through punitive damages. Yet Harvey McGregor, for instance, has argued (when editor of McGregor on Damages) that the real purpose of Lord Devlin's second category is not to punish the wrongdoer but to prevent their unjust enrichment. ${ }^{79} \mathrm{He}$ described punitive damages as a 'somewhat makeshift and arbitrary' method of achieving this end, although 'it may be that the emergence of restitutionary damages will take away from Lord Devlin's second category and render it unnecessary.' ${ }^{80}$ In the same vein, Lord Scott in Kuddus $v$ Chief Constable of Leicestershire Constabulary ${ }^{81}$ suggested that restitutionary damages could be a substitute for Lord Devlin's second category. ${ }^{82}$

Others have drawn a clear distinction between the aims of punitive and gainbased damages. While punitive damages are capable of stripping the wrongdoer of wrongfully obtained profits, this is ancillary to their intended objectives of punishment and deterrence. As Lord Diplock in Broome $v$ Cassell ${ }^{83}$ put it, "[the second category] may be a blunt instrument to prevent unjust enrichment by unlawful acts ... It is only if there is a prospect that the damages may exceed the defendant's gain that the social purpose of this category is achieved - to teach a wrong-doer that tort does not pay. ${ }^{34}$ The view that punitive damages are not simply designed

\footnotetext{
${ }^{74}$ Civ 3, 25 feb 2004, Bull civ III no 41; D 2004.1631 noted by Caron.

${ }^{75}$ Since the 1760s: see, for their historical origins, J Edelman (ed), McGregor on Damages, 20th edn (London, Sweet \& Maxwell, 2017) para 13-002.

${ }^{76}$ Rookes (n 66) 1221 (Lord Devlin).

${ }^{77}$ Fay v Parker $53 \mathrm{NH} 342,382$ (1873) (Foster J).

${ }^{78}$ Burrows (n 65) 338-52.

${ }^{79} \mathrm{H}$ McGregor, McGregor on Damages, 17th edn (London, Sweet \& Maxwell, 2003) paras 11-028 and 11-046.

${ }^{80} \mathrm{ibid}$ para 11-046; in the new edition now edited by James Edelman (n 75), it is argued that the rationale for Lord Devlin's second category is punishment or deterrence. Punitive damages are not simply designed to operate as an indirect method for extracting profits tortiously obtained by the defendant: paras 13-048-13-051.

${ }^{81}$ Kuddus v Chief Constable of Leicestershire Constabulary [2001] UKHL 29, [2002] 2 AC 122.

${ }^{82}$ ibid [109].

${ }^{83}$ Broome v Cassell [1972] AC 1027 (HL).

${ }^{84}$ ibid 1130.
} 
to serve as an indirect means for stripping profits seems to have been accepted in recent cases. ${ }^{85}$

\section{B. Tackling Profitable Wrongs in English Contract Law}

The position in English contract law is quite different. Punitive awards are not available for breach of contract. This rule has been attributed to the decision in Addis $v$ Gramophone Company Limited. ${ }^{86}$ Common objections to the awarding of punitive damages for breach of contract are that it would impair commercial predictability and the concept of punishment is not easily applicable in the context of private agreements in which rights and duties are allocated by mutual consent. ${ }^{87}$

The unavailability of punitive damages in contract law is consistent with the relatively liberal approach that English courts have historically adopted to contractual breach and the motives of the defaulting party, including whether they act deliberately, cynically or in bad faith. ${ }^{88}$ Contract law has no regard to blame. There is no general duty to behave honestly and in good faith. As Lord Hoffmann made clear in Cooperative Insurance Society Ltd $v$ Argyll Stores (Holdings) Ltd, ${ }^{89}$ 'the purpose of the law of contract is not to punish wrongdoing. ${ }^{90}$

Profitable breaches of contract are in exceptional circumstances met with the gain-based remedy of an account of profits. In Attorney-General v Blake, ${ }^{91}$ a majority of the House of Lords held that an account of profits could be awarded for a breach of contract where other remedies are inadequate and the injured party has a legitimate interest in depriving the defaulting party of their profit. The potential for gain-based awards to deter and punish has, however, been weakened by

\footnotetext{
${ }^{85}$ See the new edition of McGregor (n 75) citing Geraldine Andrews QC in Ramzan v Brookwide Ltd [2010] EWHC 2453 (Ch), [2011] 2 All ER 38. For a recent discussion of these issues, see J Goudkamp, 'Exemplary Damages' in G Virgo and S Worthington (eds), Commercial Remedies: Resolving Uncertainties (Cambridge, Cambridge University Press, 2017) 318; in the context of Australian consumer law, see E Bant and J Patterson, 'Should Specifically Deterrent or Punitive Remedies Be Made Available to Victims of Misleading Conduct under the Australian Consumer Law?' (2019) 25 Torts Law Journal 99.

${ }^{86}$ Addis v Gramophone Company Limited [1909] AC 488 (HL). But see Goudkamp (n 85) on Addis $v$ Gramophone.

${ }^{87}$ For a full discussion of the objections to punitive awards for breach of contract and their counterarguments, see N McBride, 'A Case for Awarding Punitive Damages in Response to Deliberate Breaches of Contract' (1995) 24 Anglo-American Law Review 369; J Edelman, 'Exemplary Damages for Breach of Contract' (2001) 117 LQR 539; E McKendrick, 'Breach of Contract, Restitution for Wrongs and Punishment' in A Burrows and E Peel (eds), Commercial Remedies: Current Issues and Problems (Oxford, Oxford University Press, 2003) 93; A Tettenborn, 'Punitive Damages - A View from England' (2004) 41 San Diego Law Review 1551; R Cunnington, 'Should Punitive Damages be Part of the Judicial Arsenal in Contract Cases?' (2006) 26 Legal Studies 369; J Edelman, 'In Defence of Exemplary Damages' in CEF Rickett (ed), Justifying Private Law Remedies (Oxford, Hart Publishing, 2008) 225; Rowan (n 49); Goudkamp (n 85).

${ }^{88}$ Rowan (n 49).

${ }^{89}$ Cooperative Insurance Society Ltd v Argyll Stores (Holdings) Ltd [1998] AC 1 (HL).

90 ibid 15.

${ }^{91}$ Attorney-General v Blake [2001] 1 AC 268 (HL).
} 
their exceptionality. While deterrence was central to Blake, the House of Lords was unequivocal that an account for profits should be ordered only in the narrowest of circumstances. It has therefore been rare for a defaulting party to be deprived of all the profits arising from their contractual default, at least in the context of commercial disputes. ${ }^{92}$ The courts have been more willing to make awards of partial disgorgement, ${ }^{93}$ but these have been analysed as compensatory rather than gain-based or punitive. ${ }^{94}$

Following the recognition in Attorney-General v Blake of a gain-based remedy in a contractual context, a growing number of commentators have argued that the remedial regime for breach of contract should be further reinforced by the introduction of punitive damages. The recognition in Canada that punitive damages can be available in contract claims has reinforced the view that the rule could be ripe for reconsideration. ${ }^{95}$ Nevertheless, the courts have thus far been unmoved. ${ }^{96}$

The confinement in England of punitive awards to tort law matches Article 1266-1, which applies to tort but not contract law. ${ }^{97}$ However, the rationale is different. The reasons that are cited in France include that parties can if they wish elect to have a deterrent and punitive remedy by inserting a penalty clause into their contract; and the risk that civil penalties in a contractual context may be too radical and controversial, and could deter international businesses from opting for French law as their governing law in cross-border contracts. ${ }^{98}$ In other words, the parties are able to provide for punishment if they think it desirable, something that is not possible under English law due to the rule that penalty clauses are unenforceable.

This restriction on the scope of Article 1266-1 is surprising given that the mechanisms proposed in the Catala and Terré projects and also in an earlier draft of Article 1266-1 were intended to apply in contract law. Morally reprehensible breaches that are committed with a view to making a gain or making a saving are not unusual in a contractual context, as illustrated for instance by a series of Canadian cases on insurance companies' withholding indemnification so as to coerce the insureds into lower settlements. ${ }^{99}$ It is all the more surprising that, as explained earlier, deterrence and punishment are already present in French

\footnotetext{
${ }^{92}$ eg Esso Petroleum Co Ltd v Niad Ltd [2001] EWHC Ch 458.

${ }^{93}$ eg Experience Hendrix LLC v PPX Enterprises Inc [2003] EWCA Civ 323, [2003] 1 All ER (Comm) 830.

${ }^{94}$ Morris Garner v One Step (Support) Ltd [2018] UKSC 20, [2019] AC 649.

${ }^{95} \mathrm{eg}$ Royal Bank of Canada v W Got Associates Electrical Ltd [1999] 3 SCR 408; Whiten $v$ Pilot Insurance Co 2002 SCC 18, [2002] 1 SCR 595; Fidler v Sun Life Assurance Co of Canada 2006 SCC 30, [2006] 2 SCR 3.

${ }^{96}$ Rowan (n 49).

${ }^{97}$ In an earlier published version of Art 1266-1, its scope was broader and included contract law: see Catala (n 43)

${ }^{98}$ S Carval, 'Le projet de réforme de la responsabilité civile', JCP 2017.401; J-S Borghetti, 'Un pas de plus vers la réforme de la responsabilité civile: présentation du projet de réforme rendu public le 13 mars 2017' D 2017 770; T d'Alès et L Terdjman, 'L'introduction envisagée de mécanismes répressifs dans le droit de la responsabilité civile: le Rubicon sera-t-il franchi ?’ AJ Contrat 2017.69.

${ }^{99}$ See n 95
} 
contract law, for example in the disapplication of the remoteness rule for deliberate breaches and the enforcement of penalty clauses. ${ }^{100}$ It is also evident in the central importance of specific performance, which is meant to deter breach and can seem almost punitive in some circumstances due to there being very few restrictions on the remedy. ${ }^{101}$

Only the pre-contractual period, which is governed by tort law principles, will be within the scope of Article 1266-1. Contractual negotiations are already given strong protection in French law. Article 1112 of the Civil Code provides that negotiations must satisfy the requirements of good faith, and Article 1112-1 imposes a general duty to provide information (devoir d'information). A party who does not disclose information with a view to gain or making a saving will therefore be faced not only with the threat of compensatory liability, but also with exposure to liability for a civil penalty. ${ }^{102}$

\section{The Degree of Punishment in English and French Civil Law}

The enactment of draft Article 1266-1 would therefore in many ways align French law more closely with English law and bring about a rapprochement between the two regimes. As in English law, French law would tackle profitable wrongs with a punitive sanction that would apply in tortious situations only. Nevertheless, there would remain significant differences, for example as to the beneficiary of the penalty and the level of the penal award. The strong public dimension of the proposed civil penalties is likely to cause greater stigma, as well as potentially being more severe, than any English law remedies.

\section{A. The Beneficiary of the Punitive Sanction}

An intriguing feature of Article 1266-1 is the diversion of the penalty to a compensation fund whose purpose it is to counteract the negative consequences of the wrongful conduct. Where no relevant fund exists, the penalty will be paid to the state. In contrast with England, it cannot be paid to the victim. This feature has been welcomed by many French commentators as avoiding an undesirable windfall for the victim. Where the money is paid into a compensation fund, it is put to the honourable use of repairing the harm caused. It promotes the value of 'social solidarity. ${ }^{103}$ This is particularly easy to imagine in respect of wrongs that cause

${ }^{101}$ Rowan (n 22). New Art 1221 has introduced 'manifest proportionality' as a limitation of the remedy, but commentators have argued that the courts are unlikely to feel restrained by it.

102 Prorok (n 41).

${ }^{103}$ Cappelletti (n 38).
} 
environmental harm, which in the prevailing political climate of growing environmental awareness and concern has obvious attractions.

One significant difficulty with directing the penalty to a fund, or the state if no such fund exists, is that the victim will have no financial incentive to seek the penalty. Few would bring a claim in the knowledge that they cannot benefit thereby. Indeed, to claim this form of relief might even be regarded as burdensome and likely to increase legal fees, which will hardly appeal to prospective claimants. The current scheme is also likely to lead to the courts' being reluctant to inflate, as they currently do, the compensatory award for non-pecuniary loss to avoid the risk that the wrongdoer is punished twice. This could dilute still further the incentive of the victim to claim the relief. ${ }^{104}$ Another potential problem is that the scheme could be vulnerable to abuse in settlement negotiations. The victim could seek to obtain an inflated amount of compensatory damages in exchange for a promise not to seek a civil penalty, thereby preventing the compensation fund or the state from receiving the award. ${ }^{105}$ For these reasons, many commentators have argued that the court should also have been given the power to order civil penalties of its own motion, so as to improve the efficiency of the mechanism. ${ }^{106}$

Concern about creating such a tactical incentive was one of the reasons cited by the English Law Commission for refusing to recommend that part of punitive awards should be allocated to a person other than the victim. ${ }^{107}$ Unlike in Article 1266-1, there is no jurisdiction in England for part of a punitive award made in civil litigation to be allocated to a compensation fund or the state. The scheme that was ultimately rejected by the Law Commission involved 33 per cent of the total punitive award's being payable to the state or a public fund. As well as the risk of abuse in settlement negotiations, the cost of administering and enforcing the scheme was thought to be disproportionate to the likely amount of punitive damages in issue. ${ }^{108}$

In an effort to address this problem, draft Article 1266-1 provides that the ministere public (the state) can claim the penalty where the victim does not. This would extend the role of the ministère public as the guardian of the public interest beyond its current remit of prosecuting crimes for the benefit of society into the civil sphere. Punishment in tort law would have a hybrid nature. It would be triggered by the breach of a private duty but would nevertheless see the state playing an important role. This would contrast with punishment in English tort, which is concerned only with protecting private rights and involves one individual claiming and obtaining relief from another.

\footnotetext{
${ }^{104}$ Dreyer (n 5) [14].

105 Javaux (n 34).

${ }^{106}$ As was the case in a previous version of the draft bill.

${ }^{107}$ Law Commission, Aggravated, Exemplary and Restitutionary Damages (Law Com No 247, HMSO, 1997) pt V, para 1.150 et seq.

${ }^{108}$ ibid para 1.158 .
} 


\section{B. The Level of the Penal Award}

Draft Article 1266-1 also contains guidance on quantifying civil penalties. An award should be proportionate to the seriousness of the fault, the financial means of the wrongdoer and the profit gained from the wrongful conduct. These criteria resemble those in England for assessing punitive damages. English courts take into account, amongst other things, the gravity of the wrongdoer's conduct, their wealth, ${ }^{109}$ the conduct of the parties up to the time of judgment and in particular whether the wrongdoer has expressed regret, ${ }^{110}$ the level of compensation awarded and the extent to which that award already incidentally punishes and deters the wrong, and any criminal penalties already imposed. ${ }^{111}$

Where the principles in England and France differ significantly is in the severity of the penalty. In English law, while the amount of a punitive award should reflect the seriousness of the wrongdoer's conduct, it should nevertheless be moderate. Any penalty must be the minimum necessary to achieve the dual purposes of the remedy, namely punishment and deterrence. In other words, courts should keep a sense of proportionality. ${ }^{112}$ An oft-cited instance of the courts' applying the principle of proportionality is the defamation case John $v M G N,{ }^{113}$ in which the Court of Appeal substituted the jury's punitive damages award of $£ 275,000$ with the sum of $£ 50,000$. Sir Thomas Bingham MR regarded the award made by the jury as 'manifestly excessive' and 'well beyond the minimum sum needed' to punish the newspaper and deter it and others from similar behaviour. ${ }^{114}$

It has been shown that, in practice, punitive awards are indeed modest, or at least 'anything but excessive,', 15 and there has been considerable uniformity in their amounts. An empirical study by James Goudkamp and Eleni Katsampouka, which examines every decision in which punitive damages were sought between 1 January 2000 and 31 December 2015, shows that, in relation to Lord Devlin's second category, the mean and median awards were $£ 12,082$ and $£ 5,158$ respectively, with most punitive awards (whether falling within Lord Devlin's first or second category) between $£ 588$ and $£ 33,851$. In not a single claim was the amount awarded even close to a seven-digit figure.

\footnotetext{
${ }^{109}$ Broome (n 83) 1081. The empirical study of Goudkamp and Katsampouka (n 70) 116-17 suggests that the courts apply this principle.

${ }^{110}$ Rookes (n 66) 1226-27 (Lord Devlin); Broome (n 83) 1071.

${ }^{111}$ Rookes (n 66) 1228 (Lord Devlin); see also the empirical study of Goudkamp and Katsampouka (n 70) 117-18, which concludes that in practice it 'appears that there is a loose positive relationship between the size of punitive damages awards on the one hand and the quantum of both aggravated damages and compensatory damages awards on the other. Accordingly, the size of the loss suffered by the claimant seems to affect the size of punitive damages awards.'

${ }^{112}$ Broome (n 83) 1081, where Lord Hailsham said that juries should be 'fully aware of the danger of an excessive award'.

${ }^{113}$ John v MGN [1997] QB 586 (CA).

114 ibid 626.

${ }^{115}$ Goudkamp (n 85) 114-15.
} 
These awards would probably seem toothless to the authors of the draft bill. While paragraph 2 of draft Article 1266-1 requires the court to assess the quantum of civil penalties in a proportionate manner, unlike in England, paragraph 3 gives considerable discretion to the court by setting the limit on the amount that can be awarded very high, at 10 times the profit resulting from the wrong. ${ }^{116}$ In some respects this seems incoherent. If paragraph 2 requires the penalty to be proportionate to the profit resulting from the wrong, it seems odd that under paragraph 3 the profit made can be multiplied so aggressively when calculating the award. Regardless, what is clear is that the amount can be high. This has been met with ire from some commentators, who have described it as 'unacceptable' and 'verging on extravagance.'117

That the punishment can be severe ${ }^{118}$ is all the more evident in paragraph 4 of Article 1266-1. This provides that where the wrongdoer is a company, the ceiling can be up to 5 per cent of its yearly turnover in France. ${ }^{119}$ It appears that the potentially higher limit is intended to reinforce the punitive function of civil penalties; companies generally have greater financial means than individuals and it is thought appropriate to hit them harder. ${ }^{120}$ This, however, has been criticised by some academic commentators and has been characterised as 'repressively delirious' by one. ${ }^{121}$ It is certainly easy to see how it could lead to extreme results. Staying with the earlier example of Total, its turnover in France in 2017/2018 was US $\$ 47.716$ billion $^{122}$ and 5 per cent of this amount would lead to a civil penalty of US $\$ 2.385$ billion. This is in stark contrast with the modest amounts awarded in England.

The potential extreme severity of civil penalties has led many commentators to argue that some of the safeguards found in the criminal law should be applied in this context. ${ }^{123}$ In particular, it has been noted that Article 1266-1 does not comply with the 'principle of legality of crimes and sanctions' (principe de légalité des délits et des peines), which is cardinal in French criminal law and provides that, without a basis in a legal text, there can be no punishment. The main problem with Article 1266-1 is that it contains no clear and precise definition of 'fault with a view to gain or making a saving', leading to calls to provide such a definition. ${ }^{124}$

\footnotetext{
${ }^{116}$ Borghetti (n 20) [49]; Dreyer (n 5) [7].

${ }^{117}$ Dreyer (n 5) [11].

${ }^{118}$ Dreyer (n 5) [8]; Graziani (n 5).

${ }^{119}$ In the previous draft of the bill, the ceiling was $10 \%$ of its yearly global turnover!

${ }^{120}$ Borghetti (n 20) [49].

${ }^{121}$ Dreyer (n 5) [9].

${ }^{122}$ Total, Document de Référence 2018 at www.total.com/sites/default/files/atoms/files/ddr2018-fr pdf accessed 22 March 2020.

${ }^{123}$ A criticism that has also been made in English law: Broome (n 83) 1087 (Lord Reid); Burrows (n 65) 374-78.

${ }^{124} \mathrm{C}$ Jauffret-Spinosi, 'Les dommages-intérêts punitifs dans les systèmes de droit étrangers' LPA 20 Nov 2002, 8; Behar-Touchais (n 47) 41-42; Carval (n 48) [11]-[17]; Dreyer (n 5) [8]-[11]; Prorok (n 41).
} 


\section{Insurance}

Article 1266-1, paragraph 5 of the draft bill would forbid insurance against the risk of being ordered to pay civil penalties. The justification is that if liability to pay a civil penalty were an insurable risk, the financial impact on the wrongdoer would be reduced. This would correspondingly dilute its retributive and deterrent effects.

In this respect, Article 1266-1 diverges from English law, which allows insurance against punitive damages awards. In Lancashire County Council v Municipal Insurance Ltd, ${ }^{125}$ Simon Brown LJ said that punitive damages were still 'likely to have punitive effect ${ }^{126}$ despite their being insurable. A wrongdoer who makes an insurance claim in respect of liability to pay a punitive award might subsequently face higher premiums and possibly even difficulties renewing cover. ${ }^{127}$

This principle seems well accepted in England. In its report on Aggravated, Exemplary and Restitutionary Damages, ${ }^{128}$ the Law Commission recommended that punitive damages should be insurable. It cited four main reasons: the interest in punishing and deterring the wrongdoer and appeasing the victim is futile if the wrongdoer cannot pay; ${ }^{129}$ the insurance industry, in controlling the availability and cost of insurance, can exert significant pressure on present and future insureds; ${ }^{130}$ the court and the legislature should not lightly interfere with commercial agreements; ${ }^{131}$ forbidding insurance would result in conflict between the insurer and the wrongdoing insured, who would seek to maximise the size of any compensatory award if he could achieve a commensurate diminution in any punitive award, whereas the insurer would prefer the opposite outcome. ${ }^{132}$

These divergences across the Channel further illustrate that the new civil penalty in France could be materially more severe than punitive damages under English law. Civil penalties are clearly intended to land a direct blow on the wrongdoer's finances. Unless they are insolvent, they will always have to pay something, however moderate. Unlike in England, it also shows a preference for the court rather than the insurance industry to decide the extent of the punishment.

\section{Conclusion}

The draft bill contemplates that civil penalties will become a formal weapon to deter and punish tortious wrongdoing that is committed with a view to making a

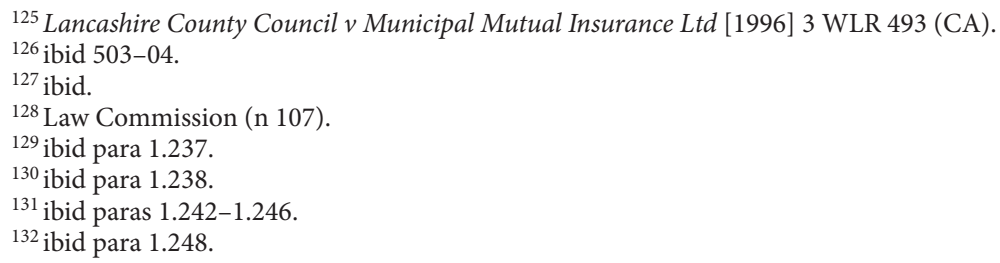




\section{Solène Rowan}

gain or a saving. Since the effects of such wrongs are not neutralised by the existing arsenal of remedies, additional weaponry is needed. If enacted, Article 1266-1 would also bring French law closer to English law. Both jurisdictions would sanction profitable wrongs through punishment.

There is, however, a real risk that Article 1266-1 will not appear in the Civil Code, at least in its current form. The lack of definition of 'fault with a view to gain or making a saving, as well as the severity and potential extremity of the penalty, will no doubt attract criticism when considered by Parliament. The compromise solution of gain-based damages to target profitable wrongs might in the end be more attractive. Yet civil penalties and gain-based damages should not be seen as interchangeable, as they have different rationales and different effects. While gainbased damages deprive the wrongdoer of their ill-gotten profits and punish them indirectly, civil penalties are a much stronger remedy and would reinforce the law more significantly.

An alternative solution would be for the draftsmen to rework Article 1266-1. Its perceived failings could be addressed by defining 'fault with a view to gain or making a saving', providing more guidance as to how the quantum of civil penalties should be assessed and reducing the maximum penalty. Whilst it is doubtful that punitive damages awards that are as modest as those in English law would be adopted as a model because they are likely to be perceived as lacking teeth, more moderate penalties would increase the prospect of draft Article 1266-1's obtaining legislative approval. 